\title{
Quality of date palm cultivars response to storage at different days intervals
}

Ghani Gul ${ }^{1}$, Naveed Ahmad ${ }^{1}$, Nadeem khan ${ }^{1 *}$, Javed Iqbal ${ }^{1}$, Ashfaq Ahmed $^{1}$, Syed Asim Shah Bacha ${ }^{1}$, Suliman Shah ${ }^{2}$, Shakil Ahmad ${ }^{3}$ and Awais Khan ${ }^{4}$

1. Department of Horticulture, The University of Agriculture, Peshawar-25130 -Pakistan

2. Department of Entomology, The University of Agriculture, Peshawar-25130 -Pakistan

3. Department of Plant Protection, The University of Agriculture, Peshawar-25130 -Pakistan

4. Department of Agronomy, The University of Agriculture, Peshawar-25130-Pakistan

*Corresponding author's email: nadeemaup25@gmail.com

Citation

Ghani Gul, Naveed Ahmad, Nadeem khan, Javed Iqbal, Ashfaq Ahmed, Syed Asim Shah Bacha, Suliman Shah, Shakil Ahmad and Awais Khan. Quality of date palm cultivars response to storage at different days intervals. Pure and Applied Biology. Vol. 5, Issue 4, pp1193-1199. http://dx.doi.org/10.19045/bspab.2016.50143

\begin{tabular}{llll}
\hline \hline Received: 26/08/2016 & Revised: 24/10/2016 & Accepted: 27/10/2016 & Online First: 31/10/2016 \\
\hline
\end{tabular}

Abstract

The research on "Quality of date palm cultivars response to storage at different days intervals" was carried out at Agriculture Research Station, Sarai Nawrang Lakki Marwat, Khyber Pakhtunkhwa during the year 2014. The experiment was laid out in Completely Randomized design (CRD) with two factors repeated three times. The fruits harvested from date cultivars (Khudravi, Abdullahwali, Azadi and Shakri), were kept for a period of $(0,4,8,12,16$ and 20 days). The storage performance of date cultivars such as weight loss (\%), decaying percentage, yellow color $(\%)$, brown color $(\%)$ and black color $(\%)$ of fruits were significantly observed. Cultivar Azadi showed the lowest weight loss (6.39\%), decaying (0.50\%), black color (45.29\%) and maximum brown color (25.39\%), yellow color (25.39\%), while lowest weight loss $(0 \%)$, decaying $(0 \%)$ on 0 days, maximum black color (100\%), minimum yellow color (0\%) and brown color $(0 \%)$ noted on 20 days of storage. Interactive effect of cultivar Azadi and 20 days storage intervals perform better for minimum weight loss, decay percentage, yellow color, brown color and maximum black color, hence recommended for the postharvest life of date palm.

Keywords: Quality; Storage intervals; Cultivars; Date palm; Phoenix dactilyfera L.

\section{Introduction}

Date palm (Phoenix dactilyfera L.) belongs to the plant family (Arecaceae). Longer dates from the crop of non-conventional important that informs both for local consumption or for export, is of Arab production of dates about $70 \%$ of global production, however, the nearly $49 \%$ of the productivity that is exported, while in Egypt amounts to productivity more than 1.1 million tons per year [1]. Despite this low average exports to 10 thousand tons per year, accounting for less than $1 \%$ of the total volume of the crop. It the only indigenous wild desert plant definitely domesticated in its native harsh environments appears to be the date palm [2]. The date palm is a typical tree of the desert oasis and rivers. It likes high temperatures, dry air and sunshine. Rains or high atmospheric humidity late in the development of fruit or during blossoming limits date growth to about the 
same extent as inadequate heat. The date palm is therefore confined to arid or semiarid regions [3]. Date palm is extensively cultivated for its edible fruit. It is used on both fresh and dry forms. Being rich in sugar it is a source of energy. Most of the carbohydrates in date in the form of fructose and glucose are easily absorbed by the human body. The fruit of date palm is composed of a fleshy pericarp and seed [4].

At harvesting stage there are high respiration rate and ripening of the cultivars of the date palm fruits that leads to perishable during storage interval. However, it is important to reduce the postharvest losses of date fruits after harvesting. Fresh and quality fruits availability to the consumer during the whole year, and increase their market value, development of postharvest technologies related to quality maintenance and life extension of date cultivars $[5,6]$. It is highly susceptible to chilling injury and mechanical damage. During storage and transportation soft rot of guava fruits caused by Rhizopus stolonifer [7]. Removing of field heat and store at room temperature reduce the decay of fruits. Proper covering, postharvest treatment with chemical and hot water, long term refrigeration for improving fruits resistance to chilling injury and diseases [8]. Postharvest applications with calcium chloride during ripening stage have been used to delay aging or ripening, efficiently reducing postharvest decay and controlling many diseases in fruits and vegetables [9]. Essential oil extracted from lemon grass (Cymbopogon citreatus DC.) and olive oil has antifungal activity against several plant pathogens [10]. In Pakistan 20-40\% of fruits losses of fruits occurs are due to improper management of postharvest operation and lack of advance techniques.

Thus critical evaluation of different packaging materials for storage stability of different cultivars of date fruits is crucial to avoid post-harvest losses. For this reason the present study was designed to find out the best storage time and variety for prolonging the postharvest life of guava fruits.

\section{Materials and methods}

An experiment to investigate "Quality of date palm cultivars response to storage at different days intervals" an experiment was conducted in Agriculture Research Station Sarai Nawrang Lakki Marwat, Khyber Pakhtunkhwa during the year 2014. The experiment was laid out in Completely Randomized design (CRD) with two factors repeated three times. Fruits of four cultivars of dates (Khudravi, Abdullahwali, Azadi and Shakri) were collected from orchard located in station. Date fruits were stored in paper carton for 20 days with storage intervals (fresh, 4, 8, 12, 16 and 20 days). Data was recorded for weight loss (\%), decaying percentage $(\%)$ and color change (Yellow color, Brown color and Black color).

\section{Statistical analysis}

The data calculated on different parameters were subjected to Analysis of Variance (ANOVA) technique to observe the differences between the different treatment as well as their interactions. In cases where the differences were significant, the means were further assessed for differences through least significant difference (LSD) test. Statistical computer software, MSTATC (Michigan State University, USA), was applied for computing both the ANOVA and LSD [11].

\section{Results}

\section{Weight loss (\%age)}

Comparing the mean values related to weight loss as recorded for cultivars and storage intervals, the maximum weight loss $(8.78 \%)$ was recorded in cultivar Shakri, at par with followed by cultivar Abdullahwali $(8.06 \%)$. While cultivar Azadi was recorded with the minimum weight loss $(6.39 \%)$. Similarly in case of storage intervals the maximum weight loss $(9.58 \%)$ was 
recorded after 12 days, while no weight loss was recorded at first day. Interactive effect of cultivar Khudravi after four days, the highest weight loss $(14.3 \%)$ was recorded in fruits, while the minimum $(9.6 \%)$ was recorded in fruits taken from cultivar Abdullahwali after eight days

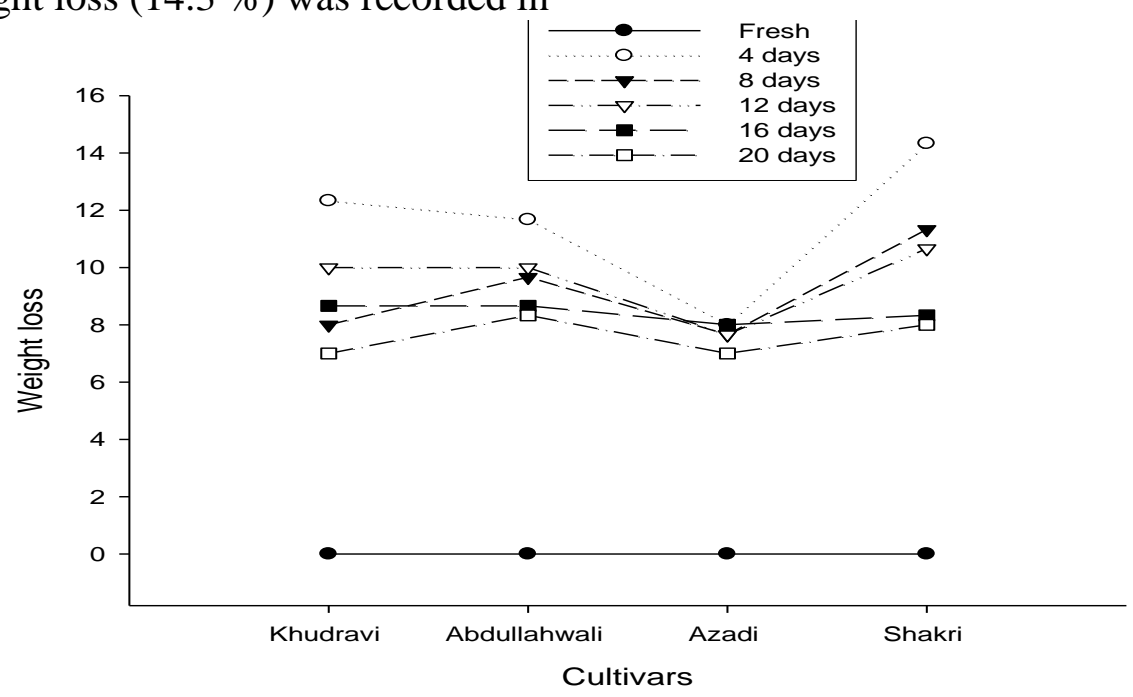

Figure 1. Interaction between cultivars and storage intervals affects weight loss

Decaying (\%age)

Data regarding decaying percentage as recorded for cultivars, the maximum decaying percentage $(2.88 \%)$ was recorded in cultivar Shakri. However the cultivar Azadi was recorded with the minimum decay percentage $(0.50 \%)$. Similarly storage intervals the maximum decaying percentage $(4.5 \%)$ was recorded after 20 days, while the minimum $(0 \%)$ was recorded at first day. In case of interaction the highest decaying percentage $(6 \%)$ was recorded in fruits harvested from cultivar Shakri after sixteen days, while the minimum $(0 \%)$ was recorded in fruits taken from cultivar Azadi after twelve days.

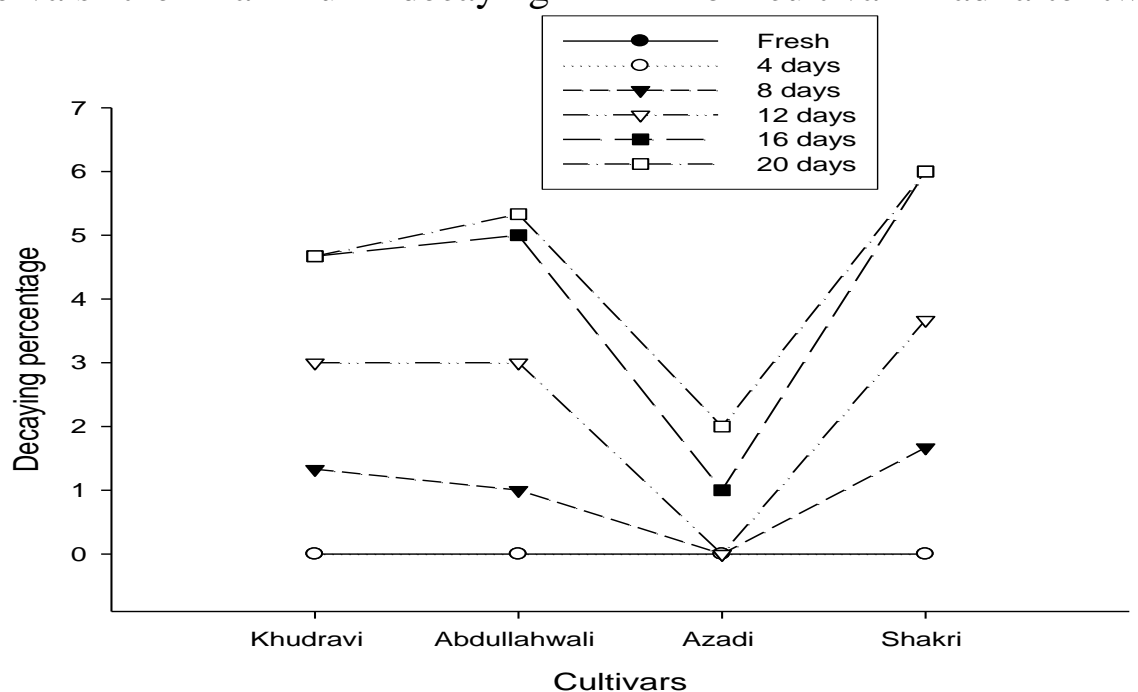

Figure 2. Interaction between cultivars and storage intervals affects decay percentage

\section{Yellow color (\%age)}

Comparing the mean values related to yellow color as recorded for cultivars, the maximum yellow color $(29.61 \%)$ was recorded in fruits harvested from cultivar Azadi. However the cultivar Abdullahwali was recorded with the minimum yellow color $(26.72 \%)$. Similarly in case of storage 
intervals the maximum yellow color (97.91 $\%$ ) was recorded on first day, while the no color was recorded after twenty days. In case of interaction the highest yellow color
$(98.00 \%)$ was recorded in fruits harvested from cultivar Khudravi on first day, while the minimum $(0 \%)$ was recorded in fruits taken from cultivar Shakri after twenty days.

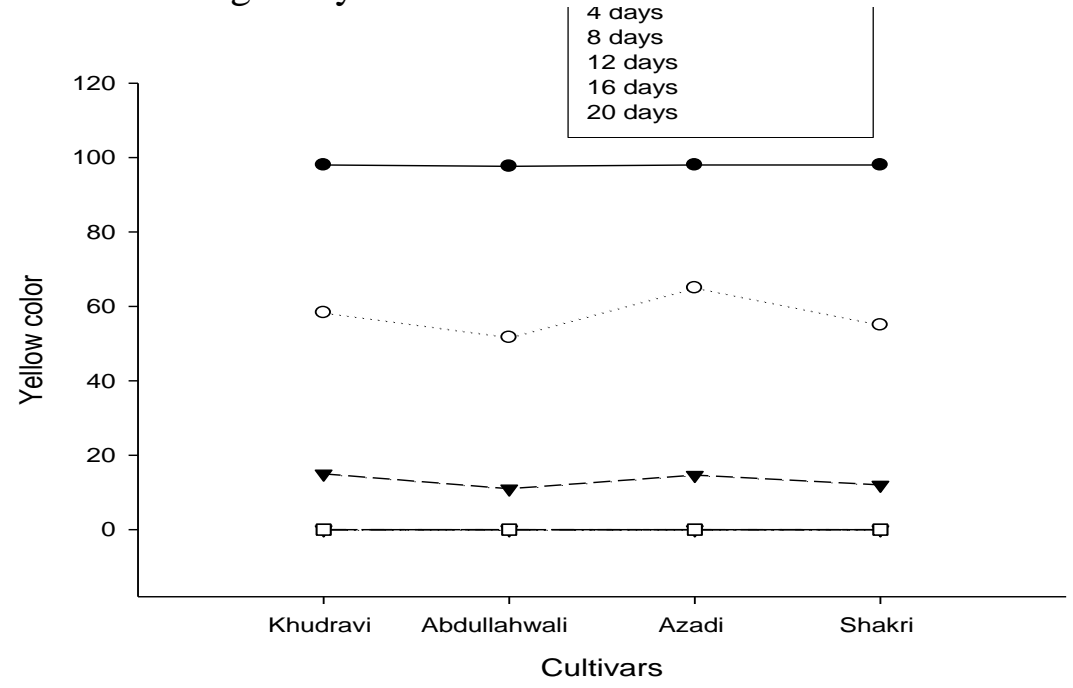

Figure 3. Interaction between cultivars and storage intervals affects yellow color

\section{Brown color (\% age)}

Mean values related to brown color as recorded for cultivars, the maximum brown color $(25.39 \%)$ was recorded in fruits harvested from cultivar Azadi. However the cultivar Shakri was recorded with the minimum brown color (18.44\%). Storage intervals the maximum brown color $(60.08$
$\%$ ) was recorded after eight days, while the minimum $(0.000 \%)$ was recorded after twenty days. Interaction between cultivars and storage intervals, the highest brown color $(72.66 \%)$ was recorded in fruits harvested from cultivar Azadi after eight days, while the minimum $(0 \%)$ was recorded all cultivars after twenty days.

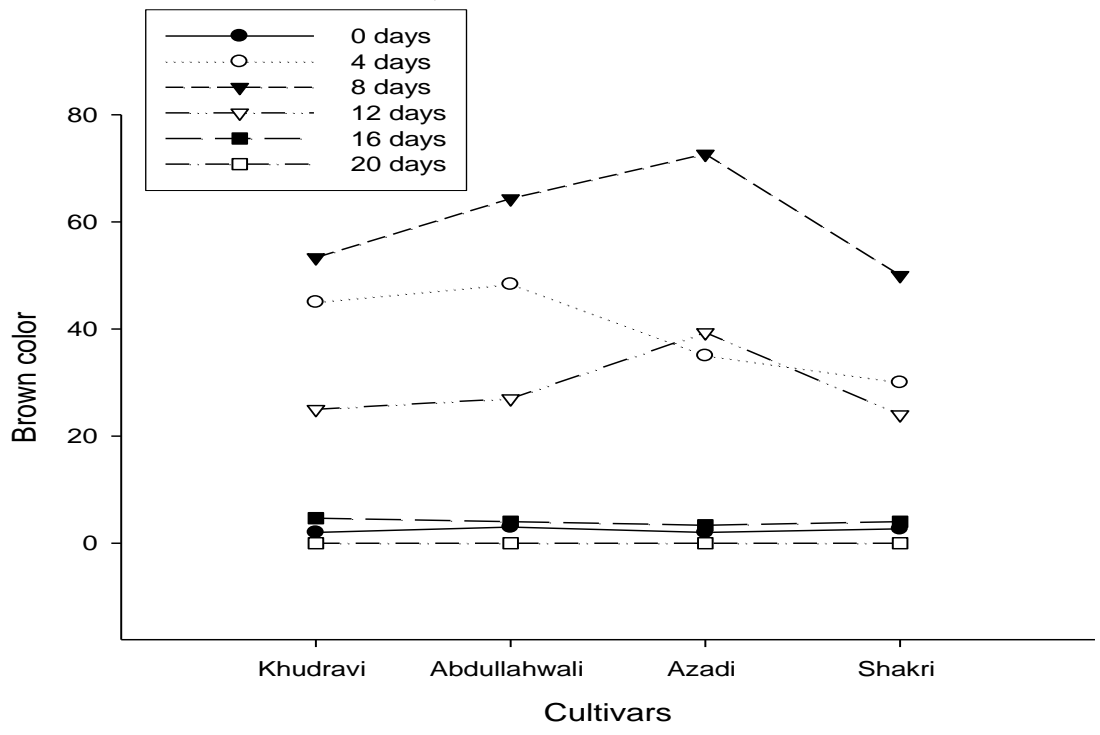

Figure 4. Interaction between cultivars and storage intervals affects brown color

\section{Black color (\% age)}

Mean data Table 1 showed that black color as affected by cultivars and storage intervals, the maximum black color $(51.78$ $\%)$ was recorded in fruits harvested from cultivar Shakri. However the cultivar Azadi 
was recorded with the minimum black color $(45.28 \%)$. Similarly in case of storage intervals the maximum black color $(100 \%)$ was recorded after twenty days, while the minimum $(0 \%)$ was recorded at first day.
Interaction, the highest black color (100\%) was recorded in fruits harvested from all cultivar after twenty days, while the minimum $(0 \%)$ was recorded in fruits taken from all cultivar on first day.

Table 1. Weight loss, decay \%, yellow color, brown color and black color as influenced by days to storage intervals and cultivars of date palm

\begin{tabular}{|c|c|c|c|c|c|}
\hline \multicolumn{6}{|c|}{ Parameters } \\
\hline Cultivars & Weight loss (\%) & Decay (\%) & Yellow Color & Brown Color & Black Color \\
\hline Khudravi & $7.67 \mathrm{~b}$ & $2.28 \mathrm{a}$ & $28.56 \mathrm{ab}$ & $21.67 \mathrm{bc}$ & $50.27 \mathrm{ab}$ \\
\hline Abdullahwali & $8.06 \mathrm{ab}$ & $2.39 \mathrm{a}$ & $26.72 \mathrm{~b}$ & $24.44 \mathrm{ab}$ & $49.16 \mathrm{~b}$ \\
\hline Azadi & $6.39 \mathrm{c}$ & $0.50 \mathrm{~b}$ & $29.61 \mathrm{a}$ & $25.39 \mathrm{a}$ & $45.27 \mathrm{a}$ \\
\hline Shakri & $8.78 \mathrm{a}$ & $2.89 \mathrm{a}$ & $27.50 \mathrm{~b}$ & $18.44 \mathrm{c}$ & $51.77 \mathrm{a}$ \\
\hline $\operatorname{LSD}_{(0.05)}$ & 0.9 & 0.7 & 2 & 3.5 & 1.5 \\
\hline \multicolumn{6}{|c|}{ Storage Intervals } \\
\hline Fresh & $0.00 \mathrm{e}$ & $0.00 \mathrm{~d}$ & $97.92 \mathrm{a}$ & $2.41 \mathrm{~d}$ & $0.00 \mathrm{e}$ \\
\hline 4 & $11.59 \mathrm{a}$ & $0.00 \mathrm{~d}$ & $57.50 \mathrm{~b}$ & $39.58 \mathrm{~b}$ & $0.00 \mathrm{e}$ \\
\hline 8 & $9.17 \mathrm{bc}$ & $1.00 \mathrm{c}$ & $13.17 \mathrm{c}$ & $60.08 \mathrm{a}$ & $27.00 \mathrm{~d}$ \\
\hline 12 & $9.58 \mathrm{~b}$ & $2.42 \mathrm{~b}$ & $0.00 \mathrm{~d}$ & $28.83 \mathrm{c}$ & $71.41 \mathrm{c}$ \\
\hline 16 & $8.42 \mathrm{~cd}$ & $4.17 \mathrm{a}$ & $0.00 \mathrm{~d}$ & $4.00 \mathrm{~d}$ & $96.33 \mathrm{~b}$ \\
\hline 20 & $7.58 \mathrm{~d}$ & $4.50 \mathrm{a}$ & $0.00 \mathrm{~d}$ & $0.00 \mathrm{~d}$ & $100 \mathrm{a}$ \\
\hline $\operatorname{LSD}_{(0.05)}$ & 1.1 & 0.8 & 2.4 & 4.4 & 1.93 \\
\hline \multicolumn{6}{|c|}{ Interaction (Cv'sxSI) } \\
\hline $\operatorname{LSD}_{(0.05)}$ & 0.9 & 0.8 & 2.2 & 3.9 & ns \\
\hline
\end{tabular}

\section{Discussion}

During the storage duration fruits decay reduces in initial days of fresh commodities and having all the physiological attributes are more in the fruits. Antifungal appearance [12] and antimicrobial activities higher when the respiration is higher and loss of sugar [13]. Disruption and death of the microbial cells decay of fruits faster [14]. [15] found that, chinitin contents of cell wall reduce loss of fruits from fungal infection. Similar studied were observed by $[16,17]$ that pathogenic microorganisms were restricted when mango fruits were coated with Chitosan. The storage life of guava fruits might be increased if the fruits are higher in calcium concentration in the plants storage life increase after removing from plants and store for later use. Loss of water from the surface of fruits, cell wall degradation, rapid respiration and ethylene concentration results to weight loss of fruits [17]. Storage of guava fruits period increase with increased in Cumulative Physiological Loss in Weight (CPLW). It might be due to increase in ethylene, respiration and loss of moisture from the surface of fruits cause significant loss in fruit weight of guava. Weight loss decrease regularly having direct effect on moisture content. Increase in weight loss, reduced metabolic activity and moisture loss from skin of the fruits [18]. Moisture levels totally depend on storage temperature and water pressure gradient between the fruit tissue and the surrounding atmosphere [19]. Softening of the fruits, loss of color, physiological changes, ethylene production and ripening process the fruits cause firmness [20]. Degree of methylation varied firmness from green and rife fruits 
mainly due to protein polymers [21], calcium which maintain adjacent chains bonded among themselves, also glycoside chains interconnected among themselves by phenolic compounds [22]. Hydrolytic enzyme activation due to ripening increased firmness that promotes intense solubilization of pectin present in the cell wall, mainly pectin methyl esterase (PME) and polygalacuronases (PG). High esterase activities in the cell wall of persimmon kernel suggest that rapid decrease in firmness [23]. It might be due to in the initial stages firmness more and ripening increase with decrease the firmness of persimmon fruit if storage time increased.

\section{Conclusion and recommendations}

Cultivar Azadi response better to all parameters in 20 days storage, hence recommended for enhancing the postharvest life of date palm.

\section{Authors' contributions}

Conceived and designed the experiments: $G$ Gul \& N Ahmad, Performed the experiments: G Gul, J Iqbal \& A Ahmed, Analyzed the data: SAS Bacha, Contributed reagents/ materials/ analysis tools: S Ahmad, S Shah \& A Khan, Wrote the paper: N Khan.

\section{References}

1. Anonymous (2008). Statistical Yearbook. Ministry of Agriculture and Land Reclamation, Giza, Egypt.

2. Zohary \& Hopf (2000). Domestication of Plants in the Old World (3rd Ed.), Oxford University Press, Oxford, UK.

3. Boudries Kefalas \& Méndez H (2007). Carotenoid composition of Algerian date varieties (Phoenix dactyliferaL.) at different edible maturation stages. Food Chem 101: 1372-1377.

4. Zaid \& Wet (1999). Date Palm Cultivation, In: Zaid AA \& Jiménez EJ (Eds.). Chapter II: Origin, Geographical Distribution and Nutritional Values of Date Palm, pp.29. Food and Agriculture
Organization of the United Nations (FAO), Plant Production and Protection pp. 156.

5. Zhong QP, Xia WS \& Jiang Y (2006). Effects of 1-methylcyclopropene treatments on ripening and Quality of harvested sapodilla fruit. Food Technol \& biotechnol 44(4): 535-539.

6. Chien PJ, Sheu F \& Yang FH (2007). Effects of edible Chitosan coating on quality and shelf life of sliced mango fruit. J Food Eng 78(1): 225-229.

7. Adisa VA (1985). Fruit rot disease guava (Psidium guajava) in Nigeria. J Indian Phytopath 38(3): 427-430.

8. Rodov V, Ben-Yehoshua S, Albagli R \& Fang DQ (1995). Reducing chilling injury and decay of stored citrus fruit by hot water dips. Postharvest Biol Technol 5: 119-127.

9. El-Gamal N, Abd GF, El-Kareem, Fotouh YO \& El-Mougy-Nehal S (2007). Induction of systemic resistance in potato plants against late and early blight diseases using chemical inducers under greenhouse and field conditions. Research conditions. Res $J$ Agri Biol Sci 3(2): 73-81.

10. Raweewon D (2008). Natural essential oils from lemon grass (Cymbopogon citrates) to control postharvest anthracnose of mango fruit. Inter $J$ Biotechnol 10: 104-108.

11. Steel RGD, Torriea JH \& Dickey DA (1997). Principle and procedure of statistic. A biometrical approach, 3rd ED. MCGRAW Hill Book Co. Inc. New York pp.172-177.

12. Hernandez AN, Hernandez $M$, Velasquez MG, Guerra MG \& Melo GE (2007). Activated antifungica del quitosano en el control de Rhizopus stolonifer (Ehreneb. FR.) Bully Mucor spp. Rev. Mex. Fitopat 25(2): 109113. 
14. Helander IM, Lassila ELN, Ahvenainen RN, Rhoades J \& Roller S (2001). Chitosan disrupts the barrier properties of the outer membrane of Gramnegative bacteria. Int J Food Microbial 71(2-3): 235-244.

15. Abbasi NK, Iqbal Z, Maqbool $M$ \& Hafiz IA (2009). Postharvest quality of mango (Mangifera indica L.) fruit as affected by Chitosan coating. Pakistan J Bot 41(1): 343357.

16. Wang J, Wang B, Jiang W \& Zhao $\mathrm{Y}$ (2007). Quality and shelf life of mango (Mangifera indica L. cv. Tainong) coated by using Chitosan and polyphenols. Food Sci Technol Int 13(4): 317-322.

17. Zhu X, Wang Q, Cao J \& Jiang W (2008). Effects of Chitosan coating on postharvest quality of mango (Mangifera indica L. cv. Tainong) fruits. J Food Process Press 32(5): 770-784.

18. Alves RE, Filgueiras HAC, Almeida AS, Pereira MEC, Cocozza FM \& Jorge JT (2004). Postharvest ripening of 'Tommy Atkins' mangoes on two maturation stages treated with 1-MCP. Acta Hort 645: 627-632.
19. Munoz PH, Almenar E, Valle VD, Velez D \& Gavara R (2008). Effect of Chitosan coating combined with postharvest calcium treatment on strawberry (Fragaria ananassa) quality during refrigerated storage. Food Chem 110(2): 428-435.

20. Oliveira ACG (2006). Conservacao poscolheita de goiaba branch Kumar poor irradiance gamma: aspects fiascos, químicos e senioritis. Boletin CEPPA 24(2): 375-396.

21. Fertonani HCR (2006). Estabelecimento de um modelo de extracao acida de pectina de bagaco de maca. Dissertacao (Mestrado em Ciencia e Technology de Alimentos)Universidade Federal de Ponta Grossa, Ponta Grossa. pp. 82.

22. Taiz L, Zeiger \& Fisiologia E (2004). Vegetal. 3. ed. Porto Alegre: Artmed. pp.719.

23. Jain N (2001). Compositional and enzymatic changes in guava (Psidium guajava L.) fruits during ripening. Acta Physiological Planetarium 23: 357-362. http://dx.doi.org/10.1007/ s11738-0010044-7. 